\title{
Investment Analysis on the Development of Polymer Modified Bitumen (PMB) Production Plant to support the building of Indonesia Infrastructures
}

\author{
Sugeng Riyadi ${ }^{1}$, Dr. Ir. Kin Tjendrasa, $\mathrm{MBA}^{2}$ \\ ${ }^{1,2}$ School of Business and Management, Institut Teknologi Bandung, Indonesia
}

\begin{abstract}
Indonesia is one of the countries that focuses on infrastructure development to support the areas of connectivity and accelerate economic growth while maintaining the global commitment to GHG emission reduction. In order to support the above objectives, competitive bitumen prices with less GHG emissions are foreseen for the infrastructure's development. Polymer Modified Bitumen (PMB) is one of the materials that is used for the pavement application that could provide $16.99 \%$ less GHG emissions compared to the unmodified bitumen due to their capability to provide similar performance with the thinner pavement layer requirement. There are 3 common PMB production processes recognized in the industry, such as Low Shear Mill Technology, High Shear Mill Technology, and Mobile PMB Plant. The Capital Budgeting technique (NPV, IRR, Profitability Index, Payback Period), internal and external analysis such as PESTEL and Porter's five forces analysis are used to support the decision making for the right technology selection for the PMB processing plant in order to stay competitive in the Bitumen market. The economic analysis has shown that the low shear technology generates an NPV of IDR 186.573.816.286 with an IRR of 75,90\%, the high shear technology generates an NPV of IDR 179.179.736.676 with an IRR of 62,39\% and the mobile PMB plant generates an NPV of IDR 243.276.282.784, with an IRR of $68,37 \%$. In addition to the highest NPV, the mobile PMB plant has the full flexibility to be mobilized to any project location, especially in remote areas where other production technologies are not available. Based on the above analysis, the mobile PMB plant is the right technology to be selected for the PMB provision to support the infrastructure development in Indonesia.
\end{abstract}

KEYWORDS: Capital Budgeting, Discounted cash flow, GHG emissions, Polymer Modified Bitumen, Project Economics, Sensitivity Analysis.

\section{INTRODUCTION}

The government of Indonesia, via the Ministry of National Development Planning (Bappenas), has set a clear path for the future of Indonesia through the rollout of Indonesia Vision 2045, where the development will be focused on four pillars: (1) Human Development and Scientific and Technological Mastery (2) Long-Term Economic Development(3) Equitable Development (4) National Resilience and Governance. Integrating infrastructure development is one of the critical success factors to support the realization of the Equitable Development pillar. The integrated infrastructures aforementioned, including the main roads for islands, rail-based transportation, air and sea transportation to support inter-region connectivity, sea transportation as the main maritime connectivity, development of aerotropolis areas, digital connectivity, fulfilment access to the basic infrastructures, and reducing the logistics cost to $8 \%$ of GDP (Kementrian PPN/Bappenas, 2019). High quality materials, such as Polymer Modified Bitumen, must be provided to support infrastructure development in order to provide reliable infrastructure, particularly for roads and airport runways. Polymer Modified Bitumen (PMB) is a modified bitumen with the introduction of additives such as Styrene Butadiene Styrene (SBS) to improve the bitumen's performance in the elasticity and flexibility areas. The introduction of SBS also provides additional benefits to bitumen, such as increasing the softening point and viscosity of bitumen (Porto et. al., 2019). The application of PMB could also provide commercial benefits in the long-term as it could increase the cost effectiveness by 2.6 times higher than unmodified mixtures (Souliman et.al., 2017). The PMB application delivers better performance from an environmental perspective as it generates lower carbon emissions in the production process compared to the unmodified mixtures. The production of an unmodified mixture generates $34.851 \mathrm{~kg}$ of CO2 per lane-km, while a modified mixture generates only $29.596 \mathrm{~kg}$ of CO2 per lane- 


\section{International Journal of Current Science Research and Review}

ISSN: 2581-8341

\section{Volume 05 Issue 02 February 2022}

DOI: 10.47191/ijesrr/V5-i2-13, Impact Factor: 5.825

$\mathrm{km}$ (Espinoza et.al., 2019). This solution is consistent with the government program through the Long-Term Strategy for Low Carbon and Climate Resilience 2050 that targets net-zero emissions in 2060 or sooner (UNFCC, 2021).

Polymer Modified Bitumen has a highly competitive market; hence, in order to stay competitive in the business, the provision of an affordable Polymer Modified Bitumen sales price through the right technology selection is an essential factor to be fulfilled. There are a few technologies available in the market for PMB production (Low Shear, High Shear, and Mobile PMB Plants) that have their own advantages and disadvantages from the Capital Expenditures (CAPEX), Operating Expenditures (OPEX), and mobilization and demobilization flexibility perspectives to be considered in technology selection. The capital budgeting approach, internal and external analysis such as PESTEL and Porter's five forces analysis, is used by the company to support the decision making of the selected technology for PMB production.

\section{LITERATURE STUDY}

A thorough assessment of the technical and non-technical, internal, and external aspects is conducted to ensure the decision taken has the most feasible and lowest risk to support the business's sustainability. Analyzing the external factors of the company is essential as it provides a strategic leader with clear visibility on threat mitigation as well as leverages the company's opportunities (Rothaermel et.al. 2021).

\section{External Analysis}

The company has conducted an external analysis prior to committing to the business to ensure that all the external factors that might impact the business continuity are properly addressed and mitigated. The external analysis also serves as a tool to scan, monitor, and evaluate the strategic leader's ability to address the required mitigation for any threat and leverage the company's opportunities to maximize the company's value.

\section{PESTEL Framework}

PESTEL analysis is one of the methods used to assess the external factors that might impact business performance. By assessing the external factors, a company could define the strategic decision to leverage the opportunity and provide necessary mitigation for any foreseen risks (Rothaermel, 2021). PESTEL analysis could be used as a tool to scan, monitor, and evaluate external factors that may have an impact on the company, allowing the company to make strategic decisions to address threats and capitalize on opportunities.

Table 1. PESTEL analysis

\begin{tabular}{|l|l|}
\hline Elements & Description \\
\hline \multirow{5}{*}{ Political } & $\begin{array}{l}\text { The demand for Polymer Modified Bitumen (PMB) is mainly for infrastructure development that consists of } \\
\text { toll roads and airport runways. As a result, any changes to the infrastructure roadmap as well as the technical } \\
\text { specifications of infrastructure will have a significant impact on the business's sustainability. To ensure business } \\
\text { sustainability, the Polymer Modified Bitumen (PMB) plant must be adaptable enough to accommodate future } \\
\text { specification changes. Maximizing the modular concept is essential to ensure the business flexibility and } \\
\text { sustainability to meet the customer's specifications. }\end{array}$ \\
\hline \multirow{5}{*}{ Economics } & $\begin{array}{l}\text { The construction sector is expected to have significant growth from 2022 onwards from non-residential } \\
\text { buildings, roads and bridges in the transportation sector, as well as oil and gas pipelines in the energy sector } \\
\text { (Fitch Solutions Group, 2021). The construction industry's growth, along with economic growth, will provide } \\
\text { an opportunity for the polymer modified bitumen (PMB) demand due to the development of infrastructure. As } \\
\text { a result, the Polymer Modified Bitumen (PMB) plant must be easily upgraded and relocated to meet market } \\
\text { demand, as well as flexible enough to be modified to meet the various bitumen specifications. }\end{array}$ \\
\hline Social & $\begin{array}{l}\text { The development of infrastructure will have an impact on sociocultural issues, particularly those concerning } \\
\text { land acquisition. Due to the bitumen constraint on heat conservation, the location of the Polymer Modified } \\
\text { Bitumen (PMB) plant must follow the area of the infrastructure project to allow its efficient and effective } \\
\text { operation. The Mobile Polymer Modified Bitumen (PMB) plant could be an alternative to minimize the impact } \\
\text { of the social friction while maintaining the local workforce support for the PMB plant operation. }\end{array}$ \\
\hline
\end{tabular}




\section{International Journal of Current Science Research and Review}

ISSN: 2581-8341

Volume 05 Issue 02 February 2022

DOI: 10.47191/ijesrr/V5-i2-13, Impact Factor: 5.825

IJCSRR@ 2022

\begin{tabular}{|l|l|}
\hline \multirow{5}{*}{ Technology } & $\begin{array}{l}\text { A fixed technology model that is less adaptable to specification changes will put the company at a competitive } \\
\text { disadvantage. Hence, the technology selection shall consider the capability to be upgraded or modified to } \\
\text { accommodate the various bitumen and additive specifications and the high flexibility to be relocated to the } \\
\text { project location as the priority criteria in the technology selection. }\end{array}$ \\
\hline Environment & $\begin{array}{l}\text { The trend of CO2 footprint reduction shall be considered in the technology selection of the Polymer Modified } \\
\text { Bitumen (PMB) Plant, whether fixed or mobile, to ensure sustainability and compliance with national and } \\
\text { international standards. The plant must be designed with the flexibility to convert from the current energy source } \\
\text { to a renewable energy source in the future. The chosen technology must have the lowest possible GHG emissions } \\
\text { to ensure its long-term viability as a business once the carbon emissions regulation is implemented in the } \\
\text { country. }\end{array}$ \\
\hline Legal & $\begin{array}{l}\text { The legal requirements for the Polymer Modified Bitumen (PMB) plant are clearly defined in Indonesia, } \\
\text { including the list of certifications and licenses that are required to operate the facilities. The modular concept } \\
\text { provides more flexibility to the approval of the license to operate as no fixed facility is constructed, hence the } \\
\text { requirement of AMDAL might change to UKL/UPL requirement. }\end{array}$ \\
\hline
\end{tabular}

\section{Internal Analysis}

\section{Porter's five forces}

The porter's five forces model provide comprehensive benefits for the leader from the 2 perspectives as defined below:

\section{Competition}

Competition is assessed broader from the five elements in Porter's five forces, as the model not only considers the competitors but also includes the impact of the buyers, suppliers, and the barrier to entry for the new competitor. Understanding the overall elements could help the leader shape a strategy that is fit for purpose to stay competitive in the industry.

\section{Profit Potential}

The profit potential of the organization could be assessed and leveraged based on the five elements defined in the Porter's Five Forces Model. Understanding the organizations' position in the specific industry could help the leader strategize the organization to maximize the profit of the organization.

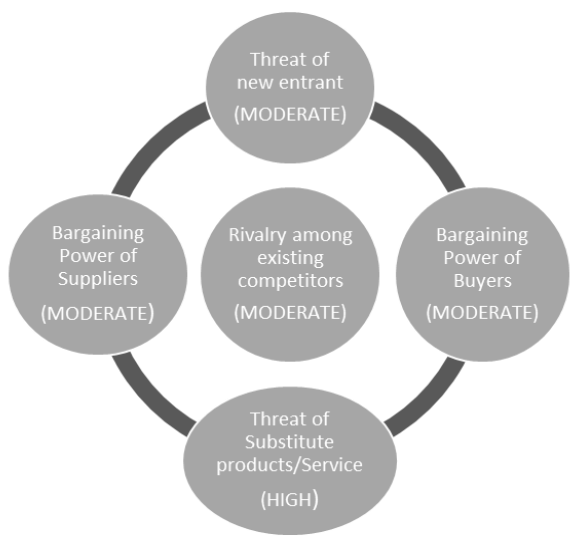

Figure 1. Porter's Five Forces Analysis

Based on the above Porter's Five Forces analysis, most of the factors are moderate except the threat of substitute products or services, which is considered high due to the numerous new products introduced to the market frequently, especially in the area of bitumen additives. The selected technology shall have the flexibility to accommodate variations in bitumen grade in order to keep the company competitive in the bitumen market.

\section{METHODOLOGY}

The study mostly used a qualitative approach to complete the assessment and analysis by using capital budgeting techniques, internal and external analysis. Primary and secondary data are used as the basis for the analysis. The primary data mainly relates to the cost 


\section{International Journal of Current Science Research and Review}

ISSN: 2581-8341

Volume 05 Issue 02 February 2022

DOI: 10.47191/ijcsrr/V5-i2-13, Impact Factor: 5.825

IJCSRR@ 2022

WwW.ijcsrr.org

estimation, project timeline, and operational cost of the similar facilities that are operated by the company, while the secondary data is used to validate the market projections that are developed by the company. The analysis is conducted for the three types of technology commonly used in the industry and the comparison of the project economics acceptance criteria is used as the baseline for the investment decision, including sensitivity analysis.

Finally, the result from the economic analysis for the three technologies will be finalized and a recommendation will be provided to the company for the best PMB technology to be selected that brings the best return for the company throughout the facility operation.

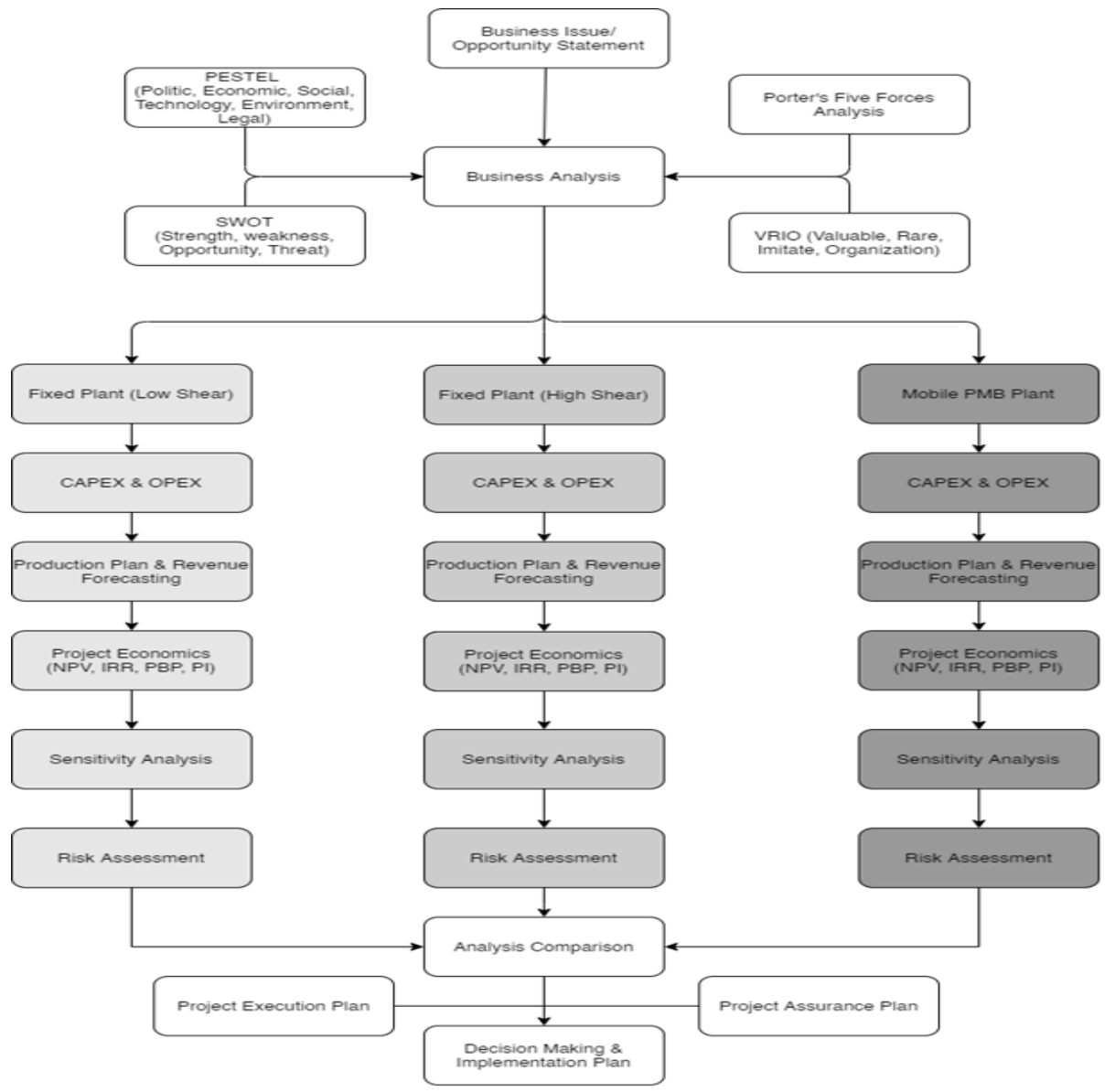

Figure 2. Conceptual Framework

\section{FINDINGS AND DISCUSSIONS}

The project economics analysis is developed based on a series of assumptions that are agreed upon by the company. (1) the source of capital is $70 \%$ from debt and 30\% from equity (2) tax rate is 20\% (based on government regulation No.1-year 2020) (3) Market share for the low shear and high shear mill technology is only at Java Island (4) Market share for PMB mobile plant is laid from central of Java up to eastern part of Indonesia (5) the plants are available for production on January 2023 (6) the WACC is $9.81 \%$ (7) economic modelling for 10 years (8) the inflation rate is $2.7 \%$ (ADB, 2021) and GDP growth rate is 3.2\% (World bank, 2021) from 2022 onwards.

\section{Low Shear Mill Technology}

The project is structured by 2 cost components that are capital expenditures (CAPEX) that mainly cover the capital cost of the facilities provision (i.e., machinery, storage facilities, etc.), while operating expenses (OPEX) mainly cover the cost of manpower and consumables to support the plant operation. 


\section{International Journal of Current Science Research and Review}

ISSN: 2581-8341

Volume 05 Issue 02 February 2022

DOI: 10.47191/ijesrr/V5-i2-13, Impact Factor: 5.825

IJCSRR @ 2022

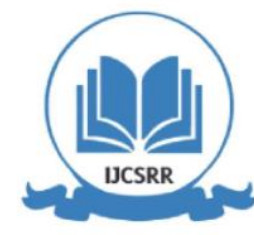

www.ijjcsrr.org

\begin{tabular}{l|c}
\hline Description & Cost (IDR) \\
\hline Storage tanks & 3.860 .075 .000 \\
\hline $\begin{array}{l}\text { Weigh bridge \& } \\
\text { gantry }\end{array}$ & 437.055 .000 \\
\hline Oil Thermal Heater & 803.250 .000 \\
\hline Screw Conveyor & 232.155 .000 \\
\hline Heat Exchanger & 703.540 .000 \\
\hline Automation System & 1.620 .000 .000 \\
\hline Building & 1.432 .890 .000 \\
\hline Fire-fighting system & 445.900 .000 \\
\hline $\begin{array}{l}\text { Laboratory } \\
\text { Equipment }\end{array}$ & 2.493 .750 .000 \\
\hline Contingency & 601.385 .000 \\
\hline Grand Total & 12.630 .000 .000
\end{tabular}

\begin{tabular}{l|c}
\multicolumn{1}{c|}{ Description } & Cost (IDR) \\
\hline Manpower & 735.800 .000 \\
\hline $\begin{array}{l}\text { Machinery } \\
\text { Maintenance }\end{array}$ & 60.000 .000 \\
\hline Electricity & 120.000 .000 \\
\hline Telecommunication & 18.000 .000 \\
\hline Stationaries & 6.000 .000 \\
\hline Truck Maintenance & 113.997 .000 \\
\hline $\begin{array}{l}\text { Operating cost e.g., } \\
\text { generator, oil thermal } \\
\text { heater, etc. }\end{array}$ & 160.305 .000 \\
\hline $\begin{array}{l}\text { Administration and } \\
\text { Marketing }\end{array}$ & $\mathbf{4 1 . 0 8 0 . 0 0 0}$ \\
\hline \multicolumn{1}{|c|}{ Grand Total } & $\mathbf{1 . 2 5 5 . 1 8 2 . 0 0 0}$ \\
\hline
\end{tabular}

Figure 3. CAPEX and OPEX (Low shear)

The revenue project is calculated based on the plant's production volume projection and the sales price of the PMB in the market for the next 10 years by adding the forecasted inflation rate for the country. The plant's production volume is developed based on the Java Island market for 10 years from Toll roads (BPJT,2021) and airport runways (DirjenHubud, 2021).

\section{High Shear Mill Technology}

The PMB production process with additional equipment called PMB skid is needed to provide larger volume of PMB through batch blending as well as providing more PMB variations.

\begin{tabular}{l|c}
\multicolumn{1}{c|}{ Description } & Cost (IDR) \\
\hline Storage tank & 3.860 .075 .000 \\
\hline $\begin{array}{l}\text { Weigh bridge \& } \\
\text { gantry }\end{array}$ & 437.055 .000 \\
\hline Oil Thermal Heater & 803.250 .000 \\
\hline Screw Conveyor & 232.155 .000 \\
\hline Heat Exchanger & 703.540 .000 \\
\hline Automation System & 1.620 .000 .000 \\
\hline Building & 1.432 .890 .000 \\
\hline Fire-fighting system & 445.900 .000 \\
\hline $\begin{array}{l}\text { Laboratory } \\
\text { Equipment }\end{array}$ & 2.493 .750 .000 \\
\hline PMB Skid & 3.850 .000 .000 \\
\hline Contingency & $\mathbf{7 9 1 . 3 8 5 . 0 0 0}$ \\
\hline Grand Total & $\mathbf{1 6 . 6 7 0 . 0 0 0 . 0 0 0}$ \\
\hline
\end{tabular}

\begin{tabular}{l|c}
\multicolumn{1}{c|}{ Description } & Cost (IDR) \\
\hline Manpower & 735.800 .000 \\
\hline $\begin{array}{l}\text { Machinery } \\
\text { Maintenance }\end{array}$ & 60.000 .000 \\
\hline Electricity & 150.000 .000 \\
\hline Telecommunication & 18.000 .000 \\
\hline Stationaries & 6.000 .000 \\
\hline Truck Maintenance & 113.997 .000 \\
\hline $\begin{array}{l}\text { Operating cost e.g., } \\
\text { generator, oil thermal } \\
\text { heater, etc. }\end{array}$ & 160.305 .000 \\
\hline $\begin{array}{l}\text { Administration and } \\
\text { Marketing }\end{array}$ & $\mathbf{4 1 . 0 8 0 . 0 0 0}$ \\
\hline \multicolumn{1}{c}{ Grand Total } & $\mathbf{1 . 2 8 5 . 1 8 2 . 0 0 0}$ \\
\hline
\end{tabular}

Figure 4. CAPEX and OPEX (High shear)

\section{Mobile PMB Plant Technology}

The PMB Mobile Plant is a modular PMB production plant where the facilities constructed in container shape $20 \mathrm{ft}$ and $40 \mathrm{ft}$.

\begin{tabular}{l|c}
\multicolumn{1}{c|}{ Description } & Cost (IDR) \\
\hline Storage tank & 2.221 .800 .000 \\
\hline Flow meter & 315.000 .000 \\
\hline Oil Thermal Heater & 803.250 .000 \\
\hline Heat Exchanger & 703.540 .000 \\
\hline Automation System & 1.620 .000 .000 \\
\hline Laboratory & $2.495 .000,000$ \\
Equipment & \\
\hline PMB Skid & $3.850 .000,000$ \\
\hline Control Room & 116.000 .000 \\
\hline Contingency & 605.410 .000 \\
\hline Grand Total & $\mathbf{1 2 . 7 3 0 . 0 0 0 . 0 0 0}$ \\
\hline
\end{tabular}

\begin{tabular}{l|c}
\multicolumn{1}{c|}{ Description } & Cost (IDR) \\
\hline Manpower & 735.800 .000 \\
\hline $\begin{array}{l}\text { Machinery } \\
\text { Maintenance }\end{array}$ & 60.000 .000 \\
\hline Electricity & 150.000 .000 \\
\hline Telecommunication & 18.000 .000 \\
\hline Stationaries & 6.000 .000 \\
\hline $\begin{array}{l}\text { Operating cost e.g., } \\
\text { generator, oil thermal } \\
\text { heater, etc. }\end{array}$ & 875.158 .050 \\
\hline $\begin{array}{l}\text { Administration and } \\
\text { Marketing }\end{array}$ & 41.080 .000 \\
\hline \multicolumn{1}{|c}{ Grand Total } & 1.863 .030 .000 \\
\hline
\end{tabular}

Figure 5. CAPEX and OPEX (Mobile PMB) 


\section{International Journal of Current Science Research and Review}

ISSN: 2581-8341

Volume 05 Issue 02 February 2022

DOI: 10.47191/ijcsrr/V5-i2-13, Impact Factor: 5.825

IJCSRR@ 2022

www.ijesrr.org

\section{Project Economics Performance}

Project economics parameters analysis are conducted for each technology and compared among them to identify the technology that provide the highest return for the investment.
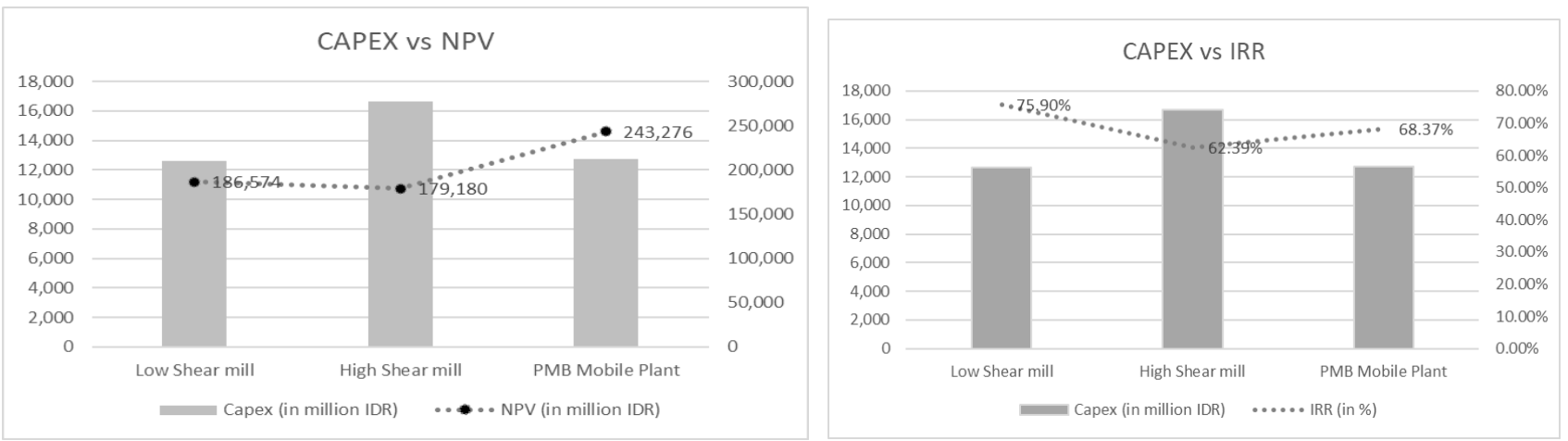

Figure 6. Project economics performance

Based on the above analysis, the Mobile PMB plant provide the highest NPV among the other technology selection due to the highest the production capacity that led to the highest revenue.

\section{Sensitivity Analysis}

The sensitivity analysis is conducted to identify the project economics changes due to changes on the underlaying assumptions. The following components are used to exercise the project economics sensitivity.

Figure 7. Sensitivity Parameters

\begin{tabular}{|l|l|l|l|}
\hline \multicolumn{1}{|c|}{ Component } & Low & Base & High \\
\hline Market share & $-30 \%$ & Base & $+30 \%$ \\
\hline PMB price & $-30 \%$ & Base & $+30 \%$ \\
\hline CAPEX & $-30 \%$ & Base & $+30 \%$ \\
\hline OPEX & $-30 \%$ & Base & $+30 \%$ \\
\hline
\end{tabular}

The sensitivity analysis is conducted for all the technology based on the project economics parameters such as NPV, IRR, profitability Index and Payback period.
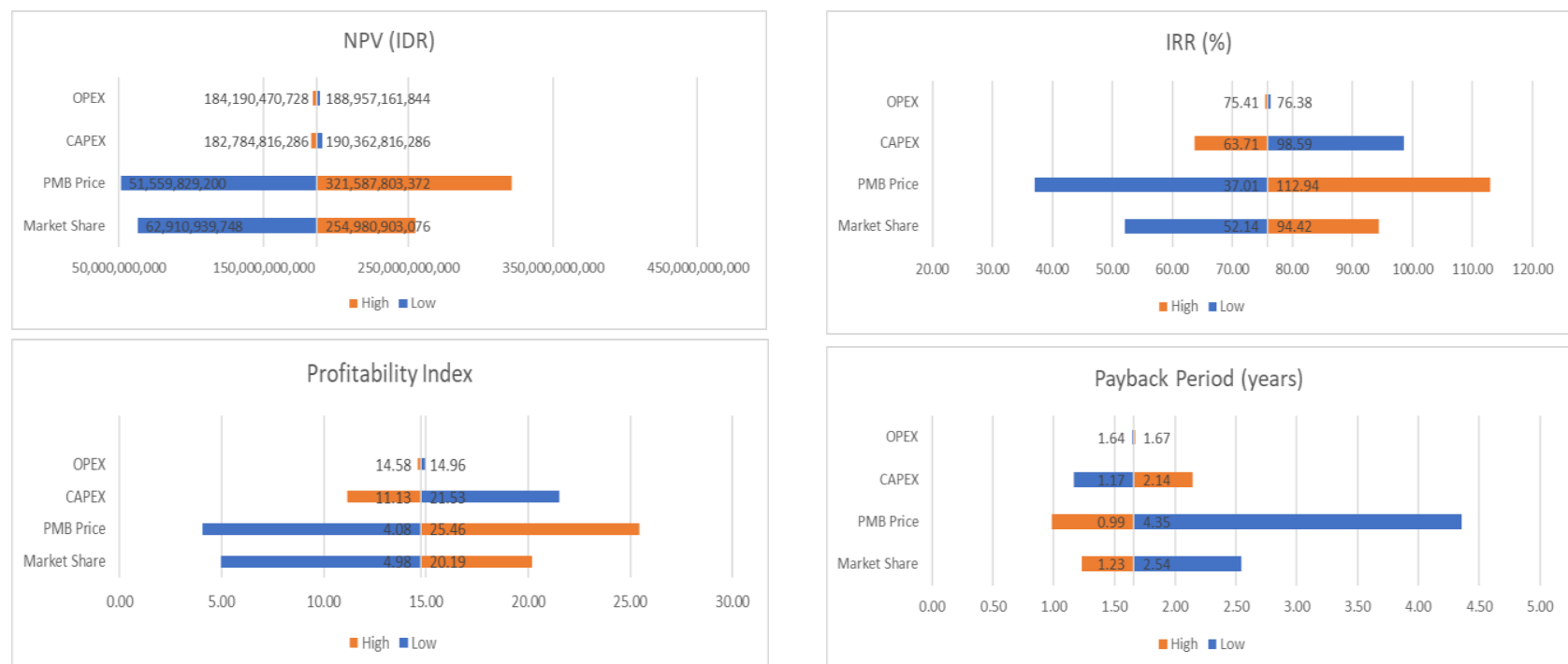

Figure 8. Sensitivity Analysis (Low Shear) 


\section{International Journal of Current Science Research and Review}

ISSN: 2581-8341

Volume 05 Issue 02 February 2022

DOI: 10.47191/ijcsrr/V5-i2-13, Impact Factor: 5.825

IJCSRR@ 2022

www.ijesrr.org

PMB price is the most sensitive components for the project economics performance. Changes $30 \%$ on the PMB price could led to $72.36 \%$ NPV reduction.
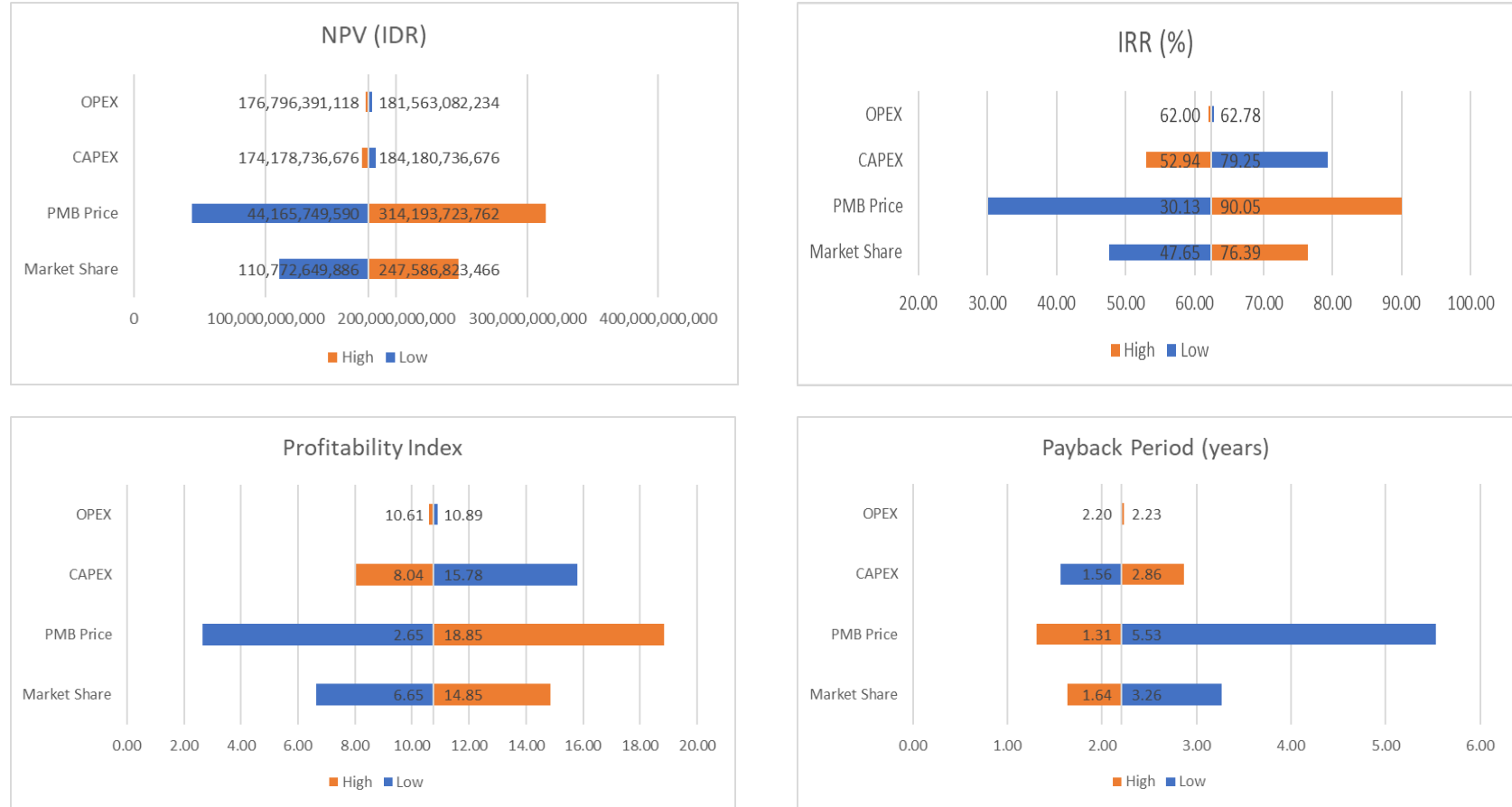

Figure 9. Sensitivity Analysis (High Shear)

PMB price has the most sensitive parameters in the NPV generation to the company. It shows that the reduction of $30 \%$ from the PMB sales price could reduce the project NPV up to $75.35 \%$ from the base case of the economic modelling.

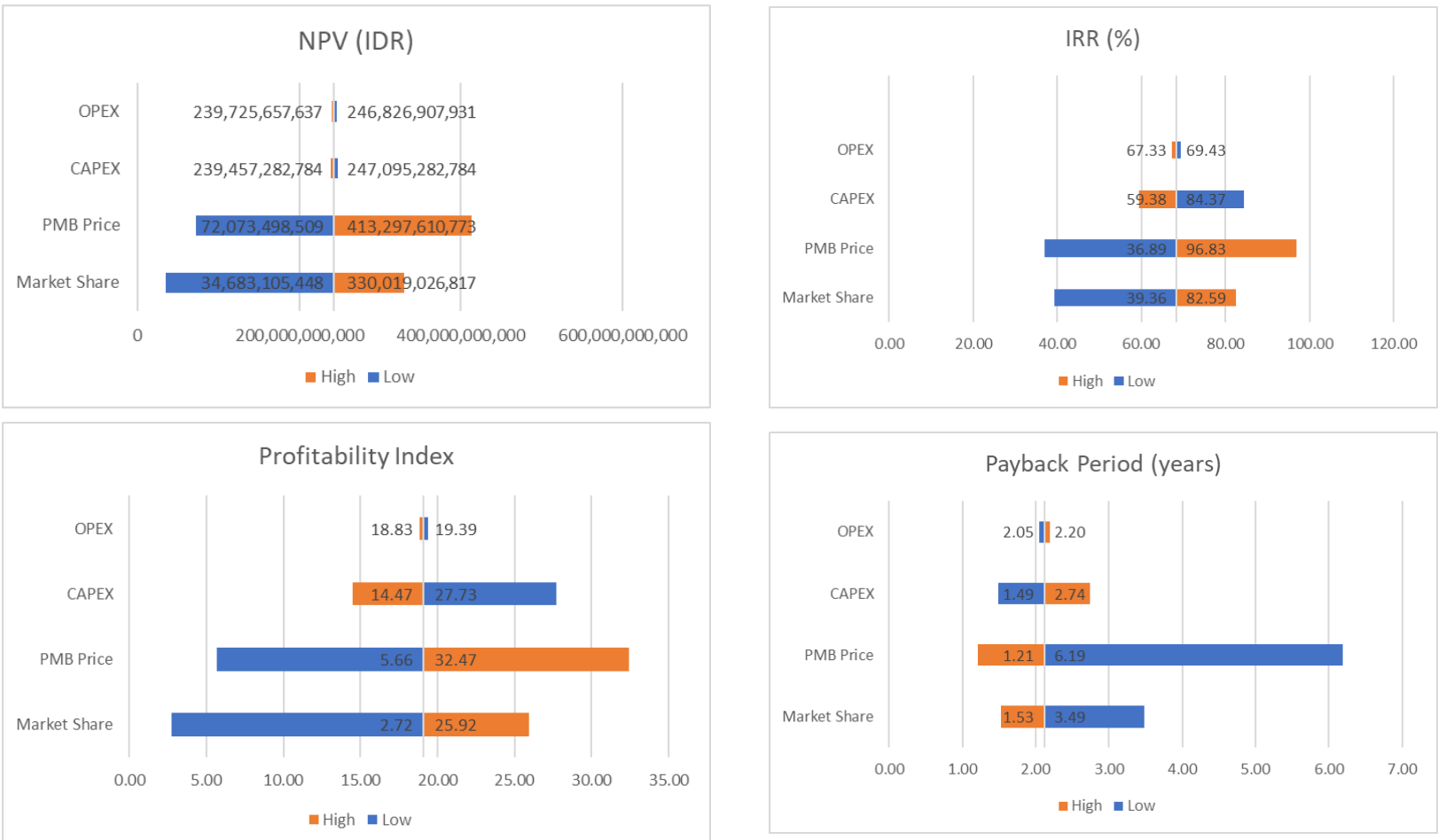

Figure 10. Sensitivity Analysis (Mobile PMB) 


\section{International Journal of Current Science Research and Review}

ISSN: 2581-8341

Volume 05 Issue 02 February 2022

DOI: 10.47191/ijcsrr/V5-i2-13, Impact Factor: 5.825

IJCSRR@ 2022

WwW.ijcsrr.org

Market share has the most sensitive parameters in the NPV generation to the company. it shows that the reduction of $30 \%$ from the PMB sales price could reduce the project NPV up to $85.74 \%$ from the base case of the economic modelling.

\section{GHG emissions for Modified and Unmodified Bitumen}

GHG emissions are calculated for modified and unmodified bitumen application for the business market projection.

\begin{tabular}{|c|c|c|c|c|c|c|}
\hline \multirow[b]{2}{*}{ Toll road } & \multirow[b]{2}{*}{ Lane } & \multirow[b]{2}{*}{$\begin{array}{l}\text { Length } \\
(\mathrm{km})\end{array}$} & \multicolumn{2}{|c|}{ Unmodified } & \multicolumn{2}{|c|}{ Modified } \\
\hline & & & $\begin{array}{c}\mathrm{KgCO} 2 \mathrm{e} / \mathrm{lane}- \\
\mathrm{km}\end{array}$ & $\begin{array}{l}\text { Total CO2 } \\
\text { (ton) }\end{array}$ & $\begin{array}{c}\mathrm{KgCO} 2 \mathrm{e} / \mathrm{lane}- \\
\mathrm{km}\end{array}$ & $\begin{array}{l}\text { Total CO2 } \\
\text { (ton) }\end{array}$ \\
\hline Tol Pejagan - Pemalang & 2 & 57,5 & 36.184 & $8.322,32$ & 30.929 & $7,113.67$ \\
\hline Tol Pemalang - Batang & 2 & 39,2 & 36.184 & $5.673,65$ & 30.929 & $4,849.67$ \\
\hline Tol Batang - Semarang & 2 & 75 & 36.184 & $10.855,20$ & 30.929 & $9,278.70$ \\
\hline $\begin{array}{l}\text { Tol Semarang Seksi } \\
\text { A,B,C }\end{array}$ & 2 & 24,8 & 36.184 & $3.589,45$ & 30.929 & $3,068.16$ \\
\hline Tol Semarang - Solo & 2 & 73 & 36.184 & $10.565,73$ & 30.929 & $9,031.27$ \\
\hline Tol Solo - Ngawi & 2 & 90,1 & 36.184 & $13.040,71$ & 30.929 & $11,146.81$ \\
\hline Tol Ngawi - Kertosono & 2 & 87,1 & 36.184 & $12.606,51$ & 30.929 & $10,775.66$ \\
\hline $\begin{array}{l}\text { Tol Jombang - } \\
\text { Mojokerto }\end{array}$ & 2 & 40,2 & 36.184 & $5.818,39$ & 30.929 & $4,973.38$ \\
\hline $\begin{array}{l}\text { Tol Krian - Legundi - } \\
\text { Bunder - Manyar }\end{array}$ & 2 & 29 & 36.184 & $4.197,34$ & 30.929 & $3,587.76$ \\
\hline Tol Surabaya - Gresik & 2 & 20,7 & 36.184 & $2.996,04$ & 30.929 & $2,560.92$ \\
\hline Tol Surabaya - Gempol & 2 & 48,9 & 36.184 & $7.077,59$ & 30.929 & $6,049.71$ \\
\hline $\begin{array}{l}\text { Tol Surabaya } \\
\text { Mojokerto }\end{array}$ & 2 & 36,27 & 36.184 & $5.249,57$ & 30.929 & $4,487.18$ \\
\hline Tol Waru - Juanda & 2 & 12,8 & 36.184 & $1.852,62$ & 30.929 & $1,583.56$ \\
\hline Tol Gempol - Pandaan & 2 & 13,6 & 36.184 & $1.968,41$ & 30.929 & $1,682.54$ \\
\hline Tol Pandaan - Malang & 2 & 38,46 & 36.184 & $5.566,55$ & 30.929 & $4,758.12$ \\
\hline Tol Gempol - Pasuruan & 2 & 34,5 & 36.184 & $4.993,39$ & 30.929 & $4,268.20$ \\
\hline $\begin{array}{l}\text { Tol Pasuruan } \\
\text { Probolinggo }\end{array}$ & 2 & 31,3 & 36.184 & $4.530,24$ & 30.929 & $3,872.31$ \\
\hline Tol Bali - Mandara & 2 & 10,1 & 36.184 & $1.461,83$ & 30.929 & $1,249.53$ \\
\hline Tol Ujung Pandang & 2 & 10,13 & 36.184 & $1.466,18$ & 30.929 & $1,253.24$ \\
\hline Tol Makassar Seksi IV & 2 & 11,6 & 36.184 & $1.678,94$ & 30.929 & $1,435.11$ \\
\hline $\begin{array}{l}\text { Tol Balikpapan- } \\
\text { Samarinda }\end{array}$ & 2 & 164,25 & 36.184 & $23.772,89$ & 30.929 & $20,320.35$ \\
\hline Total $\mathrm{CO} 2$ & & & & $137.283,54$ & & $117.345,86$ \\
\hline
\end{tabular}

Figure 11. GHG emission for modified and unmodified bitumen

The above $\mathrm{CO} 2$ emissions are calculated only for the production and construction phase, where the activity on land preparation, structure, drainage and other road construction facilities are excluded from the calculation. The typical total highway CO2 emission including the land is about 3.234,13-ton CO2e (Santosa \& Lawalata, 2019).

\section{CONCLUSIONS}

Technology selection has been conducted through the capital budgeting technique, Internal and external analysis to ensure the robust decision making are made for the PMB production plant investment.

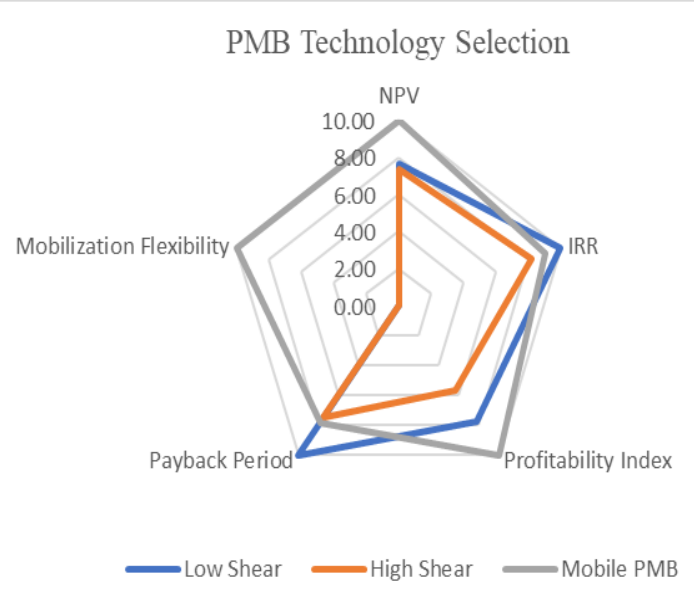




\section{International Journal of Current Science Research and Review}

ISSN: 2581-8341

\section{Volume 05 Issue 02 February 2022}

DOI: 10.47191/ijesrr/V5-i2-13, Impact Factor: 5.825

IJCSRR@ 2022

Low shear technology has provided a best IRR and Payback period. However, the technology has a significant constraint on mobilization flexibility that cannot accommodate any project in remote area unless additional facilities such as drum filling are provided.

High shear technology has an average performance for each criterion. However, with the high stirrer capacity, the facilities could produce more capacity through batch blending and deliver additional bitumen variant.

Mobile PMB Plant provide highest NPV, Profitability Index and mobilization flexibility due to their modularization concept that allows mobilization to any project site. The high stirrer capacity also allows the facilities to produce more bitumen variant.

Based on the above analysis, the Mobile PMB plant is the most recommended technology options for the PMB production facilities due to their capability to provide a highest return while maintaining their flexibility to be mobilized to any project site.

\section{REFERENCES}

1. ADB, 2021, Economic Indicator for Indonesia, available from https://www.adb.org/countries/indonesia/economy [accessed on 20 December 2021].

2. Baye, R.M., Prince, J.T.,2014, Managerial Economics and Business Strategy, New York, America: McGraw-Hill Irwin

3. BPJT, 2021, GIS BPJT. Available from https://sigi.pu.go.id/portalpupr/apps/opsdashboard/index.html\#/ad691982b770462d8e236f8ca7e450f4/ [accessed on 20 December 2021].

4. BPS, Suku Bunga Kredit Rupiah menurut kelompokbank 2021, available from https://www.bps.go.id/indicator/13/383/1/suku-bunga-kredit-rupiah-menurut-kelompok-bank.html [accessed on 28 January 2021].

5. Damodaran, Aswath, 2010, Applied Corporate Finance 3rd edition, NYU, John Wiley \& Sons.

6. Damodaran, Aswath, 2021, Country Default Spread and Risk Premiums, Available from https://pages.stern.nyu.edu/ adamodar/New_Home_Page/datafile/ctryprem.html [Accessed on 20 December 2021]

7. Datar, S.M., Rajan,M.V., 2018, Horngren's Cost Accounting A Managerial Emphasis 16th Edition, England: Pearson Education Limited.

8. Direktorat Jenderal Perhubungan Udara, 2021, Daftar Bandar Udara di Indonesia, available from http://hubud.dephub.go.id/hubud/website/BandaraListing.php [accessed on 20 December 2021].

9. Espinoza, M., Campos, N., Yang, R., Ozer, H., Aguiar-Moya, J., Baldi, A., Al-Qadi, I. 2019, Carbon footprint estimation in road construction: La Abundancia-Florencia case study. Sustainability, MDPI:9

10. Fitch Solutions Group, Indonesia infrastructure report - Q4 2021, 2021, London: Fitch Solutions Group Limited

11. IBPA, 2021, Harga dan Yield Wajar Obligasi Pemerintah Indonesia Seri Benchmark. Available from http://www.ibpa.co.id/DataPasarSuratUtang/HargadanYieldHarian/tabid/84/Default.aspx [Accessed on 20 December 2021].

12. Porto, M., Caputo, P., Loise, V., Eskandarsefat, S., Teltayev, B., \& Cesare, O. R.,2019, Bitumen and bitumen modification: A review on latest advances. Applied Sciences, 9(4):6

13. Ross,S.A., Westerfield, R.W., Jaffe, J., Jordan,B.D., 2016, Corporate Finance Eleventh Edition, New York, United States of America: McGraw-Hill Education.

14. Santosa, W., \& Lawalata, G. M., 2019, Implementasi Program Jalan Hijau Untuk Mendukung Pelaksanaan Konstruksi Rendah Karbon, Indonesia, Jurnal HPJI (Himpunan Pengembangan Jalan Indonesia), 5(2), 65-74.

15. Souliman, M., Zeiada, W., \& Walubita, L., 2017, Mechanical and economical impacts of adding polymers into asphalt mixtures. Les Ulis: EDP Sciences:9

16. World bank, 2021, The global economy on track for strong but uneven growth as covid 19 still weigh. Available from https://www.worldbank.org/en/news/feature/2021/06/08/the-global-economy-on-track-for-strong-but-uneven-growth-ascovid-19-stillweighs\#: :text=A\%20year\%20and\%20a\%20half,in\%2080\%20years\%20in\%202021.\&text= Global\%20growth\%20is\%20expected\%20to,the\%20United\%20States\%20and\%20China. [Accessed on 20 December 2021]. 


\section{International Journal of Current Science Research and Review}

ISSN: 2581-8341

Volume 05 Issue 02 February 2022

DOI: 10.47191/ijesrr/V5-i2-13, Impact Factor: 5.825

IJCSRR@ 2022

www.ijcsrr.org

17. Zutter, Chad J., Gitman, Lawrence, J., 2015, Principles of Managerial Finance Global Edition, United Kingdom: Pearson Education.

Cite this Article: Sugeng Riyadi, Dr. Ir. Kin Tjendrasa, MBA (2022). Investment Analysis on the Development of Polymer Modified Bitumen (PMB) Production Plant to support the building of Indonesia Infrastructures. International Journal of Current Science Research and Review, 5(2), 396-405 